\title{
Contemporary Factors Determining the Choice of Supermarket Patronage in Ado-Ekiti Metropolis of Nigeria
}

\author{
${ }^{1}$ OLASEHINDE Sunday Adeniyi, ${ }^{2}$ OGUNDIPE Christie Folake, ${ }^{3}$ AYODELE Oluwaseun Opeyemi \& \\ ${ }^{4}$ BANKOLE Oluwole Adeniyi
}

${ }^{1}$ Department of Business Administration

Faculty of Management Sciences

Federal University, Oye-Ekiti, Nigeria

${ }^{2-4}$ Department of Business Administration

Faculty of Management Sciences

Ekiti State University, Ado-Ekiti, Nigeria

\begin{abstract}
This study examined the contemporary factors (quality, price, assurance and distance) determining the choice of supermarkets in Ado-Ekiti Metropolis. A descriptive survey research design was adopted for the study. The population of the study constituted the walk-in customers of the selected supermarkets in Ado-Ekiti metropolis. The sample size was 200customers using random sampling. Primary data used for the study were gathered through a structured questionnaire. Data gathered were analyzed using multiple regression. The result showed that product quality positively affects customer patronage; furthermore, the result showed that product price positively affects customer patronage; more so, the result showed that assurance positively affects customer patronage and finally, distance does not significantly affect customer patronage all at 0.05 level of significance. Thus, the study concluded, that product quality, product price and assurance statistically and significantly affects customer patronage among supermarkets in Ado-Ekiti Metropolis.
\end{abstract}

Keyword: Customer Patronage, Price, Quality assurance.

\section{INTRODUCTION}

The establishment of supermarkets in Ado-Ekiti metropolis is becoming fast increasing. However, Increase competition in supermarket business and rapid technological developments have changed the point of view of business sustenanceand expansion. Previously, business financial indicators were followed to ensure the permanence of the business in a long run. In addition to these indicators in recent markets, more theoretical concepts such as customer satisfaction, customer loyalty, customer patronage and customer preference are measured to understand the prospect of the business [1].

Considering the business long-term success, businessesmust establish different strategies in increasing market share which is not sufficient to gain new customers for increasing market share in a competitive environment. Businessesmust look for ways to attract and retain customers to achieve the basic business goals for survival and expansion. These entail that business with a loyal customer portfolio have an essential competitive advantage due to repeated purchase behaviour, willingness to recommend to others, emotional attachment and price tolerance. Flourishing businesses globally have the widespread goal of strengthening their brand image through better quality [2]. Many businesses are facing tough brand war among each other for getting utmost market share in Nigeria. A company can get utmost share with the help of offering best product brand with affordable price and the availability of quality product at all time. Through providing best quality brand and the assurance of getting such product anytime by the customer create positive image in the mind of prospective buyers which may in turn affect their purchasing behaviour. Therefore, retail store or supermarkets are able to increase their market share and profitability respectively.

Similarly, for organizations to achieve huge success in a long term basis,it is necessary for organizationstowork very hard. Therefore, organizations success is determined by many factors which are patronage behaviour, profitability, market share and increased sales. Organizations earning lot of profit are not considered to be the most powerful organization business, 
thoughprofit generation is one of the organisational tasks. In the current world,retaining the old customers and concentratingon the new customers is considered to be a success [3] . To this end, the priority of every business should not be centered on profit alone but the factor that determines the profitability and stability which is the customers. Therefore, customers should be treated as king in this current world.

This research clearly attempts to verify the extentto which distance, quality, price and assurance influences the choice of patronage as well as customer satisfaction in modern time. Therefore, successful organizations work hard to build strong positive image and representing it in a constant and clear way [4]. According to [5], organizational success is a direct outcome of brand image which is considered as animportantattribute of current marketing strategy. In view of this, positive image becomes the determinant of customer satisfaction and patronage through product quality, distance, assurance and price of product which also enhances customers' patronage and result to customers' loyalty in a future time. However, product quality build positive image in the mind of customer or consumer due to its last longer value and uniqueness which is mostly considered by customer before making any purchase decision. Consequently, the role price plays on customer's satisfaction and patronage cannot be left out as it determines the strength and ability of various customers. The location or distance of a business is a germane factor that needs special attention as it tends to dictate the level of customer satisfaction. However, this factors have a serious psychological effect on customer attitude. Therefore, the assurance of getting a product and service providers responsiveness to customers go a long way in determining re-patronage behaviour as first impression will always last longer.

Apparently, from the study of [6], which found that brand image, product quality and product pricepositively and significantly affect customer satisfaction in Pakistan. However, this study will also adaptthe aforementioned variables to includedistance, product quality, product price and assuranceas the factors determining the choice of supermarket patronage in Ado-Ekiti Metropolis. The research work focused on providing relatedbusiness with feedback on factors to be considered as a strategy to increase customer patronage and how to sustain their respective customers in order to be able to survive in the competitive market. The policy makers will also obtain knowledge of the service industry dynamics and the appropriate strategies; they therefore will obtain guidance from this study in designing appropriate policies that will regulate the business.Investors will gain an insight on the business and its strategic position within the environment which can assist them in determining their viability of their investments particularly in supermarket business. This study will serve as a reference to future study in the field of marketing management.

\section{LITERATURE REVIEW}

\subsection{Factors Determining the Choice of Retail Store or Supermarket Patronage}

Numerous factors can be considered as the determinant of customer patronage in recent time but this study was limited to only four (quality, price, assurance and distance) which is consider to be the germane factors influencing the choice of customer patronage currently.

\subsection{Product Quality}

A quality in this context is described as a distinctive attribute or characteristic of a product. Therefore, product quality becomes a focal point or main target for some customers among certain category of social stratification which have penchant for quality product regardless of price and distance to get such product. The description of product quality is more complex as it is not a clearly defined concept. Product quality can be regarded as the general or particularcomprehensive value of satisfaction or purpose and uniqueness of a product. The quality of a product is more often than not relative. There is no standard measure though policies are in place to ensure adequate quality standards complied with by manufacturers [7]. Therefore, product quality becomes one of the main reasons why customers patronises supermarket in recent time. Average human being tends to see value for the money spent which makes quality so imperative in determining the choice of supermarket patronage.

\subsection{Product Price}

Pricing can be defined as a process of determining the value to be received by an organization in exchange of its products or services. Product priceacts as animportantfactorforrevenue generation to an organization. Therefore, the pricing decisions of an organization have a direct impact on its success. Product price is influenced by a numerousfactorslike manufacturing cost, competition, market conditions and quality of the product. Businesses setting product prices needs to ensure that prices must cover costs incurred for producing products and profit margins. If aproduct price does not cover costs, then financial resources of the organization would be drained which would ultimately result in business failure. Organization uses a number of technique and strategies to determine the prices of its products. The pricing strategy of any organization should be realistic, flexible, and profitable. Therefore, price should be focused on in achieving the financial goals [8]. Product price is a value attached to a 
particular product or services though pricing system varies particularly in Supermarkets but very essential on business profitability. Price is a sensitive and crucial factor determining individual preference for certain supermarket. That is, individual tends to patronize retail store or supermarket where product is relatively cheaper compared to other supermarkets. It is very certain that customers switch from one supermarket or retail store to other when one is cheaper to others. In view of this, price has to be considered when determining the choice of patronizing supermarkets.

\subsection{Assurance}

Assurance involves the knowledge and politeness of employees and their ability to display trust and confidence. This assurance includes competence, courtesy, credibility and security [9]. In view of this, assurance in this context denotes the attributes or personality exhibited by the supermarket workers through maintaining cordial relationship with customers, their responsiveness and reliability of making quality products available to customers. Businesses must display a sufficient human skills and understanding to deliver quality services to customers through displaying high level of professionalism in dealing with customers [10]. Product assurance means the friendly and polite comfort, provision or availability of product, experienced and knowledgeable employees and quick responsiveness to customers. The basic elements of assurance is perceived through customer professional services or rapid responsiveness, excellent knowledge of professional, courteous manner and good communication skills in order to meet up with customers expectation every time customers uses the service or makes order. Therefore, the concept of assurance is punctured on reliability and availability of products, responsiveness and maintaining cordial relationship with customers. To this end, assurance caters for customer's expectation, satisfaction and loyalty which tend to influence customer patronage behaviour. Whenever a customer have the assurance of getting a product in a certain place or supermarket, customers tend to make frequent patronage even without considering the cost involved incurred such as transportation and price charged on such product. In view of the above, assurance remains a major factor determining retail store or supermarket patronage currently.

\subsection{Distance}

Locations of retail store or supermarkets must be accessible to the potential customers [11]. [12] discovered that a far distance has a negative effect on the selection of a retail store through reducing frequency of customers visiting a store. Stores located in the centre of city benefit from their next door to remote customers. Therefore, we surmised that distance from home and distance from workplace would have a relationship with the amount of purchase from retail stores [13]. Consequently, distance is a fundamental factors that cannot be left out in determining patronage of supermarkets recently which other researchers neglected. Customers cut across the entire locations or geographical areas in Ado-Ekiti metropolis. However, some customers find satisfaction in patronizing distance supermarket despite having one or more in their area. Therefore, this has led to emergence of distance as one of the vital factor determining the patronage of supermarkets or retail stores in modern environment and to be sure if distance positively or negatively influences the choice of supermarket patronage in Ado-Ekiti Metropolis. Distance remains the amount of space between two places. The two places in this context is the distance from a customer geographical location and the location of the supermarkets. In view of this, one of the impediments of supermarket distance is transportation costwhich may be advantageous to some customers and be at disadvantage to other customers. To this end, distance tends to influence the choice of patronizing supermarket in modern environment.

\subsection{Patronage}

[14] defined customer patronage as the support provided by customers with respect to a particular brand. Patronage becomes the basis for any business with reputable name and increasing market share. [15] advocated that consumers have unpredictable level of patronage to particular services, stores and other entities. In view of this, the determinant of customer patronage in this context includes distance, product quality, product price and assurance of the retail store or supermarket [16]. Customer patronage can be determined by customers satisfaction, customer preference and customer loyalty. When customers are satisfied with the service of a retail store or supermarket, they either prefer to stick with such supermarket or switch to others that can meet their expectation. In view of this, satisfied customers tends to advertise or recommend to other family or friends through word of mouth because of the loyalty the business enjoyed as a result of satisfying customers need. The effective satisfaction customer enjoys will surely enhance customer patronage behaviour.

A supermarket can be described according to [17] as a business enterprise that provides services to prospective customers. In the usual sense, supermarkets do not produce a physical product of its own. Instead, it attach value through acquisition of existing products from distantly located suppliers, assembling them in regional warehouses, distributing them to local stores and finally selling the products to local customers. In view of this, the value chain started from the manufacturer to the warehouse where agents or supplier can move them to supermarkets or retail stores and finally makes them available for final consumers. In the same vein, supermarket's customers are primarily local residents and small businesses that need to replenish their stock of household products periodically. A supermarket's suppliers are primarily producers of household products that are established far from the locations of their final customers. In effect, the supermarket provides an effective marketplace that brings remote 
suppliers together with local customers. A supermarket exists in a competitive environment, where it acts as a value-added intermediary between geographically dispersed supplier companies and the spread individual customers who eventually buy their products. In carrying out its purpose, a supermarket business purchases and assembles a wide variety of goods from individual suppliers, then organizes and distributes them as needed to a chain of retail stores for sale to local customers [17].

\subsection{Conceptual Framework}

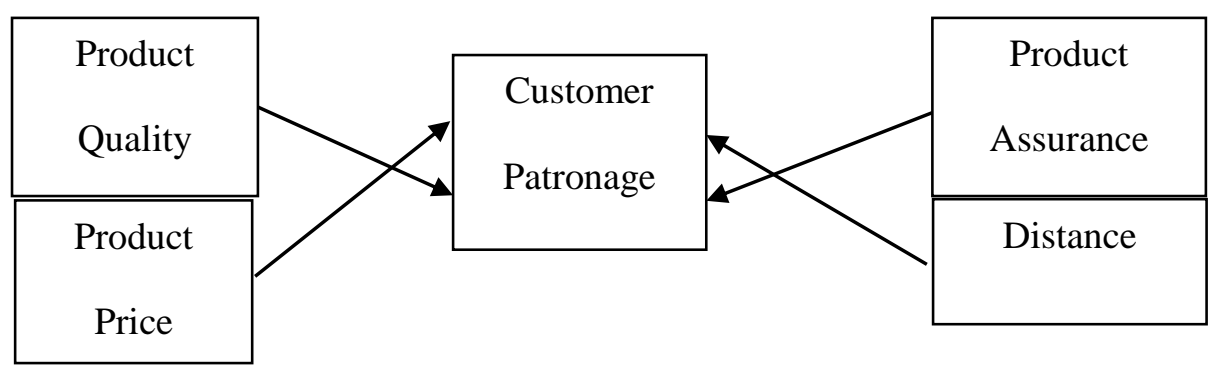

Source: Author's Conceptualization, 2020

The conceptualframe work explores the relationship between the four key variables in this study. The study showed the nexus between distance, product quality, product price, product assuranceand customer patronage. The adoption of these factors has the tendency of enhancing customer patronage particularly in supermarket business. However, the factors are not limited to these four factors more are recently found to be the key determinant of patronage in current supermarket industry.

\section{METHODOLOGY}

The study wascarried out in Ado-Ekiti metropolis, the capital city of Ekiti State. The research design used was descriptive survey. The research design allowed for contact with otherwise inaccessible participants. This study considered four supermarkets which are Starleg Supermarket, Nao Supermarket, Bruno Supermarket and Lino Supermarket in Ado-Ekiti Metropolis. Customers patronizing these supermarkets constituted the study respondents while 200 walk in customers were randomly sampled due to unavailability of customer records in the supermarkets. That is 50 customers will be selected from each supermarket bringing the total to 200 respondents. The data generated for this study wasanalysed using descriptive and inferential statistic. However, descriptive statistics were used to analyze the demographic information of the respondents through the use of frequency tableswhile inferential statistic were used to analyze the effect of the explanatory variables on customer patronage.The specific objective wasanalysed using multiple hierarchical regression analysis.

\section{DATA ANALYSIS PRESENTATION AND INTERPRETATION}

\subsection{Respondents' Demographic Characteristic}

From the questionnaires administered to the respondents, two hundred (200) questionnaires were administered, retrieved and submitted for analysis. The retrieved questionnaires were subjected to multiple regression analysis.

Table 1: Respondents Demographic Characteristic

\begin{tabular}{llr}
\hline Variables & Frequency & Percent \\
\hline Sex & & 45.0 \\
Male & 89 & 55.0 \\
Female & 111 & $\mathbf{1 0 0 . 0}$ \\
Total & $\mathbf{2 0 0}$ & \\
Age & & 47.0 \\
Below 30 & 93 & 30.0 \\
31-40 & 61 & 23.0 \\
41 Above & 46 & $\mathbf{1 0 0 . 0}$ \\
Total & $\mathbf{2 0 0}$ & 36.0 \\
Marital Status & & 61.0 \\
Single & 73 & 3.0 \\
Married & 121 & $\mathbf{1 0 0 . 0}$ \\
Divorced & 06 & $\mathbf{2 0 0}$ \\
Total & &
\end{tabular}


International Journal of Advances in Scientific Research and Engineering (ijasre), Vol 6 (2), February-2020

$\begin{array}{llc}\text { Employment Status } & & \\ \text { Civil Servant } & 92 & 46.0 \\ \text { Self Employed } & 42 & 21.0 \\ \text { Students } & 66 & 33.0 \\ \text { Total } & \mathbf{2 0 0} & \mathbf{1 0 0 . 0} \\ \text { Academic Background } & & \\ \text { University } & 117 & 59.0 \\ \text { Polytechnic } & 41 & 21.0 \\ \text { College } & 29 & 14.0 \\ \text { Others } & 13 & 6.0 \\ \text { Total } & \mathbf{2 0 0} & \mathbf{1 0 0 . 0} \\ \text { Mode of Patronage } & & \\ \text { Daily } & 68 & 34.0 \\ \text { Weekly } & 97 & 48.0 \\ \text { Monthly } & 35 & 18.0 \\ \text { Total } & \mathbf{2 0 0} & \mathbf{1 0 0 . 0}\end{array}$

Source: Field survey, 2020

Table 1 which is the sex distribution, it was shown that $4 \quad 5 \%$ of the respondents are male while $55 \%$ of the respondent are female thus implies that majority of the respondent sampled are female. Considering age distribution, it was shown that $47 \%$ of the respondents are below 30 years of age, $30.0 \%$ of the respondents are between $31-40$ years of age while $23 \%$ of the respondents are 41 years and above thus implies most of the respondents are below 30 years of age. Furthermore, from marital status, the table depicted that $36 \%$ of the respondents are single, $61 \%$ of the respondents are married while $3 \%$ of the respondents are divorced thus imply majority of the respondent are married. Considering employment status distribution, it was shown that $46 \%$ of the respondents are public servant, $21 \%$ of the respondents are self employed while 33\% of the respondents are students thus implies most of the respondents are public servants.

From academic background distribution, it was shown that $59 \%$ of the respondents attended university, $21 \%$ of the respondents attended polytechnic, $14 \%$ of the respondents attended colleges while $6 \%$ of the respondents attended other educational institution thus implies most of the respondents attended university. Mode of patronage as depicted on table 1 shows that $34 \%$ of the respondents patronizes supermarkets daily, $48 \%$ of the respondent patronizes supermarkets weekly while $18 \%$ of the respondent patronizes supermarkets monthly thus implies that majority of the respondent surveyed patronizes supermarkets weekly.

\subsection{Discussion of Findings}

Table 2: Regression Result Summary of Factors Determining Patronage of Supermarkets

\begin{tabular}{|c|c|c|c|c|c|c|}
\hline \multirow{2}{*}{$\frac{\text { Variables }}{\text { Constant }}$} & & \multirow{2}{*}{$\frac{\text { Beta }}{1.577}$} & \multirow{2}{*}{$\begin{array}{l}\text { Std Error } \\
.657\end{array}$} & \multicolumn{2}{|c|}{ T-ValueP-Value Rank } & \\
\hline & & & & 2.879 & .003 & \\
\hline Quality & & .370 & .090 & 4.329 & .000 & $1^{\mathrm{st}}$ \\
\hline Assurance & & .332 & .091 & 3.617 & .000 & $3^{\text {rd }}$ \\
\hline Price & & .333 & .092 & 3.652 & .000 & $2^{\text {nd }}$ \\
\hline Distance & & .182 & .113 & 1.611 & .112 & $4^{\text {th }}$ \\
\hline $\mathrm{R}$ & .599 & & & & & \\
\hline $\mathrm{R}^{2}$ & .359 & & & & & \\
\hline Adj R & .333 & & & & & \\
\hline
\end{tabular}

\section{Source: Field survey, 2020}

Table 2 revealed that the regression co-efficient ofdeterminant factors on customer patronage showed a positive figure of 0.599 , this indicates that quality, price, assurance and distance stronglyaffect customer patronage which implies that the explanatory variable has a positive effect on customer patronage.The co-efficient of multiple determinant $\left(\mathrm{R}^{2}\right)$ with a co-efficient of 0.359 shows that the explanatory variable can explain $35.9 \%$ of the behaviour of customer patronage while the remaining $64.1 \%$ can be explained by the stochastic variable or other variables that were not put into consideration. The adjusted $\mathrm{R}^{2}$ further confirms the result of the $\mathrm{R}^{2}$ with a co-efficient of 0.333 , which shows $33.3 \%$ explanation of the behaviour of the customer patronage by the explanatory variables after adjustment while the remaining $66.7 \%$ is explained by the error term. 
Four variables (quality, price, assurance and distance) were employed to investigate the determinant factor on customer patronage which was subjected to regression analysis. The study findings showed that quality, price, assurance and distanceare significant and positively related to customer patronage. However, the unstandardized $\beta$ co-efficient of product quality gives a positive value of 0.370 with $\mathrm{t}=4.329$ and $(\mathrm{P}=0.000<0.05)$. This showed that product quality has a significant effect on customer patronage. This variable is most significant and ranked first among other variable to explained that customer patronage is most determined by product quality. In the same vein, the unstandardized $\beta$ co-efficient of product assurance gives a positive value of 0.332 with $\mathrm{t}=$ 3.617 and $(\mathrm{P}=0.000<0.05)$. This showed that product assurance has a significant effect on customer patronage. This means that respondents' reason for customer patronage is positively influenced by product assurance which is ranked to be the third variable among the four factors determining customer patronage. Furthermore, the unstandardized $\beta$ co-efficient of product price gives a positive value of 0.333 with $\mathrm{t}=3.652$ and $(\mathrm{P}=0.000<0.05)$. This showed that product price has a significant effect on customer patronage. This means that respondents' reason for customer patronage is strongly and positively influenced byproduct price and it is ranked to be the second effective factor among other factors determining customer patronage. Finally, the unstandardized $\beta$ co-efficient of distance gives a positive value of 0.182 with $\mathrm{t}=1.611$ and $(\mathrm{P}=0.112<0.05)$. This showed that distance has a no significant effect on customer patronage. This means that respondents' reason for customer patronage is not positively influenced by distance and it is ranked to be the last factor among other factors determining customer patronage which was found insignificance. Therefore, distance will not significantly influence customer patronage of supermarkets. In view of the above fact, this shows that the product quality, product price and product assuranceare positively related to customer patronage and that only distancewas found non-significance on customer patronage. Therefore implies that an improvement in these contemporary factors will result to increases in customer patronageat 0.05 level of significance. This finding is consistent with the research carried out by [18] on the effect of service quality, price, and brand image on customer satisfaction in Indonesia. The study showed that good quality of service that meets customer expectations significantly affects customer satisfaction and loyalty.

\section{CONCLUSION}

The study evaluated the contemporary factors determining the choice or supermarket patronage in Ado-Ekiti Metropolis.The factors employed are product quality, product price, assurance and distance. However, from the findings, it was revealed that product quality has significant effect on customer patronage, Moreso, product price significantly affect customer patronage and assurance has significant effect on customer patronage but distance was found to be positive but not significant on customer patronage all at 0.05 level of significance. However, from the overall result, it was found based on ranking that product quality affects customer patronage most, followed by product price and lastly assurance. The study accepted alternate hypothesisand rejected otherwise thus concluded that product quality, product price, assurance and distance are positively related to customer patronage.

\subsection{Recommendations}

As drawn from the study findings, the study recommends that manufacturers should prioritise quality products and that supermarkets should also ensure to stock quality product as it has far reaching effect on customer patronage since customer has the positive image that quality is sold or found most in supermarkets. Moreso, price is also a major determinant supermarkets should dwell on. The price set $\mathrm{n}$ the product must be relatively fair and acceptable by the customers in order to increase patronage and at the same time increase market share. Finally, managers of supermarket should take cognisance of every stock as to replace them in time to meet the customers need on a daily basis to avoid disappointment that may lead to customer switching. Consequently, supermarket customer should establish cordial relationship that will build positive image in the mind of prospective customers as to increase their satisfaction and patronage.

\section{REFERENCES}

1. Cetin, D., Kuscu, A., Ozcam, D. A., \&Erdem, Y. C. (2016). Brand image, satisfaction and brand loyalty: How effective are they in the automotive industry market share. European journal of business and management, 8(7), 31-35.

2. Nasar, A., Hussani, S. K., Karim, E., \&Siddiqui, M. Q. (2012). Analysis of influential factors on consumer buying behaviour of youngster towards branded products: Evidence from Karachi. Kasbit business Journal, 5, 56-61.

3. Ahmed, I., Nawaz, M. M., Usman, A., Shaukat, M. Z., Ahmad, N., \&Iqbal, H. (2010). Impact of service quality on customer's satisfaction: Empirical evidence from telecom sector of Pakistan. 1(12), 98- 113.

4. Egan, J. (2014). Marketing communication. United Kingdom: SAGE Publication.

5. Kotler, P. (2001). A framework for marketing management. Upper Saddle River, NJ: Prentice Hall.

6. Malik, M. E., Ghafoor, M. M., \& Iqbal, H. K. (2012). Impact of brand image, service quality and price on customer satisfaction in Pakistan Telecommunication Sector. International Journal of Business and social Sciences, 3(23), 123-129. 
7. Jing, H., Xin, L., Sijun, W., \& Zhilin, Y. (2012). The role of brand image congruity in Chinese consumers' brand preference. Journal of Product and Brand Management, 21(1).

8. Murthi, B., \& Rao, R. C. (2012). Price Awareness and consumers and Satisfaction: A BehaviouralPerspective on the consumer. McGraw-Hill. Boston.

9. Agyapong, G. K. Q. (2011). The effect of service quality on customer satisfaction in the utility industry: A case of Vodafone (Ghana).International Journal of Business and Management, 6(5), 203-240.

10. Ojo, O. (2010). The relationship between service quality and customer satisfaction in the Telecommunication Industry: Evidence from Nigeria. Brand Broad Research in Accounting, Negotiation and Distribution, 1(1), 88-100.

11. Kotler, P., \& Armstrong, G. (2004). Principles of Marketing, Upper Saddle River, New Jersey: Pearson Education.

12. Hansen, T., \&Solgaard, H. S. (2004). Measuring the effect of distance on consumer patronage behaviour: a structural equation model and empirical results: New perspectives on retailing and store patronage behaviour: $A$ study of the interface between retailers and consumers, Boston: Kluwer Academic Publishers.

13. Chaiyasoonthorn, W., \&Suksa-ngiam, W. (2011). Factors influencing store patronage: a study of modern retailers in Bangkok Thailand. International Journal of Trade, Economics and Finance, 2(6), $\quad 520-525$.

14. Mary, S. (2016). The impact of customer service on customer patronage in banking: The mediating effect of ICT adoption. A thesis submitted to the school of business, Kwame University of science and technology. Published Thesis.

15. Kotler, P. (2007). Principle of marketing. Prentice hall, New Jersey (11 ${ }^{\text {th }} \mathrm{ed}$.).

16. Kotler, P., \& Keller, K. L. (2006).Marketing Management $\left(12^{\text {th }}\right.$ ed.). Upper Seddle River: Prentice-Hall.

17. Steeneken, F., \& Ackley, D. (2012). A complete model of the supermarket business, 1-13

18. Dimyati, M., \&Subagio, N. A. (2016). Impact of service quality, price and brand loyalty with the mediation of customer satisfaction on PosEkspres in East Java. Mediterranean Journal of Social $\quad$ Sciences, 7(4), 74-86. 